\title{
“KeeP it WiLd, KeEP it Local": Comparing News Media and the INTERNET AS Sites FOR ENVIRONMENTAL Movement Activism for Jumbo Pass, BRITISH COLUMBiA $^{1}$
}

\author{
Mark C.J. StOdDART \\ LAURA MaCDONALD
}

Abstract. Environmental movements depend on mass media to reach the public and shape political decision-making. Without media access, social movements experience political marginality. In this paper, we examine whether the internet is a more open space than traditional media for activists to speak on behalf of nature. Our analysis is based on newspaper coverage and environmental organization websites that focus on the conflict over the proposed Jumbo Glacier Resort ski resort in British Columbia. Environmental websites and mass media texts both define Jumbo Pass as wilderness and grizzly bear habitat, while focusing on ecological concerns as well as questions of local democracy. However, environmental group websites discuss a greater range of environmental risks and provide more detailed discussion of these issues. Environmentalist websites also integrate scientific experts and celebrity supporters to a greater degree than mass media texts, which are dominated by environmentalist, ski industry, and provincial government news sources.

Keywords: environmentalism; mass media; computer-mediated communication; sport, recreation and tourism; British Columbia; social movements

Résumé. Les mouvements environnementaux dépendent de la capacité des médias de masse de joindre le public et d'influencer les décisions politiques. Sans l'accès des médias, les mouvements sociaux seraient politiquement marginaux. Dans cet article, nous examinons si Internet représente un espace plus ouvert que les médias traditionnels pour les activistes désireux de parler au nom de la nature. Notre analyse repose sur la couverture médiatique des journaux et des sites

1. Acknowledgements: The authors would like to thank Dr. Howard Ramos for his input throughout this project, as well as Kelly Greenfield for her assistance in the preparation of this paper. Financial support for this research was provided by Killam Trusts. 
Web des organismes environnementaux ciblant le conflit du projet de station de ski Jumbo Glacier, en Colombie-Britannique. Les sites Web environnementaux et les textes des médias de masse définissent tous le col Jumbo comme étant une région sauvage et un habitat pour l'ours grizzly, tout en ciblant les problèmes écologiques ainsi que les questions relevant de la démocratie locale. Cependant, les sites Web des groupes environnementaux discutent d'un plus grand nombre de risques pour l'environnement et fournissent une tribune pour des discussions plus détaillées à ce sujet. Les sites Web des environnementalistes intègrent aussi les experts scientifiques et les partisans mondains dans une plus grande mesure que les textes des médias de masse qui sont dominés par les environnementalistes, l'industrie du ski ainsi que les sources de nouvelles du gouvernement provincial.

Mots clés: environnementalisme, médias de masse, communication dispensée par ordinateur, sport, loisir et tourisme, Colombie-Britannique, mouvements sociaux

So ocial movements, including environmentalism, rely on the mass media to gain visibility for their issues, to reach potential supporters, and to engage opponents and governments in public debate (Gamson 2007; Gitlin 1980; Hannigan 2006; Hansen 2010). Through media coverage, environmental movements attempt to challenge and transform North Americans' understanding of the global climate, old growth forests, and our interactions with wildlife. In this way, the mass media have a profound effect on the ways in which nature becomes political.

We examine the case of eco-political conflict over Jumbo Pass - the site of a proposed ski resort in British Columbia - to analyze how the internet functions as a more open public sphere than traditional mass media for environmentalist communication. Conflict over the development has lasted over twenty years, involving resort proponents, several environmental movement organizations, and a succession of New Democratic Party (NDP) and Liberal provincial governments. Environmentalists oppose the development because it risks disrupting local wildlife populations, particularly grizzly bears. Jumbo Glacier Resort was granted "Resort Municipality" status by the provincial government in 2009 and the project continues to move slowly forward, despite ongoing opposition from environmental groups. In this paper, we compare newspaper coverage of this conflict from the Vancouver Sun, Globe and Mail, and National Post, with an analysis of web content produced by the environmental organizations cited in news media coverage.

A large body of research focuses on media coverage of eco-political conflict over forestry practices in British Columbia (Arvai and Mascarenhas 2001; Cormier and Tindall 2005; Doyle et al. 1997; Rossiter 2004; Stoddart 2005). Far less work focuses on environmental move- 
ment mobilization against tourism and outdfoor recreation, whether in B.C. or elsewhere (Barnes 2009; Kousis 2000; Stoddart 2011). Outdoor recreation and nature tourism are often assumed to be environmentally benign, particularly in comparison with natural resource extraction. Environmental movement mobilization around the ecological harms of tourism and recreation must disturb these assumptions in order to be successful. Little attention has been paid to environmentalists' use of media within the limited body of research in this area.

Our research fills this gap by focusing on environmental movement uses of media in conflict over the proposed Jumbo Glacier Resort. Environmental websites and mass media texts both define the region as wilderness and grizzly bear habitat, while also focusing on issues of local democracy. There is a degree of consonance between mass media representations of the Jumbo conflict and claims made through environmental websites. However, environmentalist websites go beyond mass media coverage as they discuss a greater range of environmental risks and provide more detailed discussion of these issues. Our results support claims that the internet increases the capacity of social movements to raise substantive issues and mobilize supporters (della Porta and Mosca 2005; Earl and Kimport 2011; Rohlinger and Brown 2009). However, the modes of political participation encouraged online are heavily guided and work on a model of simplifying and "supersizing" traditional forms of activism, rather than generating new modes of protest (Earl and Kimport 2011).

\section{Theoretical Framework}

The relationship between social movements and journalists has been characterized as one of "asymmetrical dependency" (Carroll and Ratner 1999). Journalists enjoy the discretion to select stories and news sources. As a result, social movement organizations must make their issues newsworthy enough to gain coverage. This is often done by engaging in dramatic acts of protest, including civil disobedience or large rallies (Boykoff 2006; Doyle 2003; Smith et al. 2001). While creating drama and spectacle may gain access for social movements, the substantive content of movement claims can be weakened or lost altogether. The relationship between movements and media often involves a trade-off between quantity of coverage (level of access to news sources) and quality of coverage (the ability to convey substantive messages).

The emergence of the internet as an "alternative public sphere" is altering the relationship between movement actors and news workers 
(Hackett and Carroll 2006; Lester and Hutchins 2009; Owens and Palmer 2003). The internet may give social movements greater independence and power to raise substantive issues, promote citizen engagement, and speak directly to supporters than traditional mass media (della Porta and Mosca 2005; Earl and Kimport 2011; Rohlinger and Brown 2009). However, a higher degree of audience "motivation" (Schroder 2000) is required to seek out and view social movement websites than is necessary to engage with general audience newspapers or television. As Owens and Palmer (2003) note, mass media coverage continues to play an important role for social movements because it can motivate readers to seek out the specialized content of movement websites.

Several characteristics of the internet facilitate collective action. The internet enhances the tactical repertoires of social movements through online petitions and other forms of "five-minute activism," as well as by opening up possibilities for forms of collaboration that do not require physical co-presence (Earl and Kimport 2011). Internet technologies are less costly than other media in terms of time and money, and can be used to communicate and coordinate action across geographically distant sites (della Porta and Mosca 2005; Earl and Kimport 2011; Rohlinger and Brown 2009). Internet activism has become a familiar technique for several social movements, such as the anti-neoliberal globalization movement, and is lauded for making collective action more reflexive (Carroll and Hackett 2006; Juris 2008; Wilson 2007).

The internet allows social movements to create information first hand or with sources of their choosing. This circumvents some of the obstacles associated with gaining entrée into mass media, such as failing to recognize the voices of marginalized populations, or even circulating deliberate misinformation (Hackett et al. 2000; Schudson 1989). Using the internet as a communications tool may allow social movements to tilt the asymmetrical power balance that is characteristic of mass media (Lester and Hutchins 2009). However, because traditional news sources, including newspapers and television, continue to carry influence, gaining mass media exposure remains an important objective for many social movement actors (Cottle 2008).

There is growing interest in Web 2.0 applications among social movements, including You Tube, RSS feeds, blogs, Facebook, and Twitter. New media technologies go beyond providing a one-way process of information sharing. Instead, they emphasize collaboration, participation, and two-way dialogue between content creators and audiences (Greenberg and MacAulay 2009; Song 2008). This shift has a significant effect on organizations who wish to develop an online presence in order to recruit participants, influence policy, and achieve movement goals 
related to fundraising, education programs, or broader social change. Given that most Web 2.0 applications are free, nonprofit organizations are expected to appreciate and learn to benefit from these changes (Stein 2011). Web 2.0 applications and website development are described as beneficial to social movements, but they tend to be underused by environmental organizations (Greenberg and MacAulay 2009; Stein 2011). This is particularly noteworthy because nonprofit organizations are frequently early adopters of new technology (Cukier and Middleton 2003).

Website audiences are another important consideration when analyzing environmental organizations' internet use. The internet allows organizations to send "targeted information to multiple constituents, including the public, the press, decision-makers, lawmakers, and existing and potential supporters" (Stein 2011:372). For example, Stein (2011:376) interviewed 28 environmental group webmasters and found that each organization listed several intended audiences with current members, supporters, and journalists as primary intended audiences for their websites, followed by potential members, potential supporters and the general public. The ability to reach multiple audiences provides clear advantages for environmental organizations. However, as Becker (2002:340) argues, "The image of an inert, passive mass audience is a gross empirical error." This is illustrated through the proliferation of Web 2.0 applications and increased levels of participation among internet users worldwide. The open ended and malleable features of computer technology allow a wide range of interpretations among viewers (Orlikowski 1992:421). Audiences also judge website quality and functionality based on their first impressions of the homepage, which creates challenges for organizations attempting to convey detailed information in scientific or economic research (Greenberg and MacAulay 2009; Stein 2011).

\section{Methodology}

We combine textual analysis of news articles published in major national and provincial newspapers with an analysis of websites produced by environmental organizations involved in the Jumbo Pass conflict (Macdonald 2003; Mason 2002; Silverman 2001). In July 2009, we used the Factiva database to sample articles from the Globe and Mail and the $\mathrm{Na}$ tional Post, the two daily newspapers with national circulation. A keyword search produced a sample of 25 articles about Jumbo Pass (16 from the Globe and Mail and 9 from the National Post), published between 1983-2009 (23 of these were published between 2003-2009). We also used Factiva to sample 10 articles on Jumbo Pass from the Vancouver 
Sun, the larger of the two British Columbia newspapers with provincewide distribution. This set of articles was published between 2002 and 2005. The newspaper texts were imported to NVivo 8 software for qualitative analysis. Coding and analysis focused on which organizational actors appeared as news sources, how the Jumbo Pass landscape was defined by different news sources, which claims and counterclaims were made about ecological degradation in the area, which forms of land use were seen as appropriate for the area, and which mechanisms of political decision-making were discussed.

Internet research is an increasingly useful approach for the social sciences, especially when combined with traditional research methods (Hesse-Biber and Levy 2008; Hine 2005; Lindlof and Shatzer 1998). Internet ethnography of online communities or websites is one way to use the internet as a methodological tool (Hine 2005). Advantages of internet ethnography include the relative ease of collecting and recording data and its unobtrusive design. Internet ethnography shares some features of a traditional ethnography, including detailed description and field notes, but it differs because a virtual space is observed, rather than a physical one (Hesse-Biber and Levy 2008). As there are often no physical barriers to restrict website access, the space must be clearly defined before conducting research. We bound our internet ethnography by sampling websites developed by organizations cited in mass media coverage of the Jumbo Pass conflict. These organizations include the Jumbo Creek Conservation Society, Wildsight, the Valhalla Wilderness Society, and the Nelson EcoSociety (now the West Kootenay EcoSociety). A field note protocol listed several key questions that guided the data collection process. Once information from websites was collected, in fall 2009, the data was imported to NVivo 8 for coding and analysis.

Our initial observations found little evidence of connections between environmental organization websites and Web 2.0 applications. As conflict over Jumbo Pass is ongoing, in summer 2011 we carried out further data collection on activists' use of Web 2.0 technologies. We searched the key words "Jumbo Pass," "Jumbo Wild," and "Jumbo Glacier Resort" on Facebook, Twitter, Wikipedia, and You Tube. We then analyzed links between these websites and environmental organization websites to examine how environmentalists are making use of the "affordances" of Web 2.0 technologies to extend their reach to a broader audience (Earl and Kimport 2011). While environmental organizations make use of Facebook and You Tube as sites for advocating on behalf of Jumbo, searches of Twitter and Wikipedia produced no results. 


\section{Results}

Our analysis focuses on three main dimensions of the Jumbo Pass conflict. First, we focus on the cultural meanings of Jumbo Pass articulated by the mass media and through environmental organization websites, with attention to the modes of interaction with this mountain environment that are viewed as ecologically legitimate and illegitimate. Second, we focus on the ways in which environmentalists articulate concerns about local democracy and environmental governance through news media and through activist-produced web content. Third, we focus on the protest tactics used by environmentalists to gain attention for their claims on behalf of Jumbo in the mass media and online. We conclude with a brief discussion of the use of Web 2.0 technologies to expand the reach of environmentalist claims-making on behalf of Jumbo Pass.

\section{Tourism, Development and Ecological Risk in the Purcells}

\section{Mass media}

The most prevalent mass media theme, which is articulated primarily by environmentalists, is of Jumbo Pass as a wilderness landscape in need of protection from skiing development (12 out of 36 news articles). The construction of wilderness represented in the news narrative recalls Nash's (2001:3) description of contemporary understandings of wilderness as places where "the absence of men [sic] and the presence of wild animals is assumed." The local grizzly bear population, which is invoked in 13 articles, is a key focal point for environmentalist claims-making. The following example from the National Post cites a prominent environmentalist news source from the Jumbo Creek Conservation Society:

Building what amounts to a village on Jumbo Glacier would endanger "an ecological treasure," said Meredith Hamstead, a spokeswoman for Jumbo Creek Conservation Society. "There are species issues and habitat issues." According to Ms. Hamstead, the proposed site of the resort in [sic] the path of a trail used by grizzly bears and a habitat for other species as well. (Greenwood 2004a:FP01)

In this discourse, grizzly bears stand in for wildlife impacts and threats to nature in general. This is consistent with prior research on the symbolic work that animals are called upon to do within environmental politics (Philo and Wilbert 2000; Wolch and Emel 1998). Grizzly bears, and wildlife in general, rarely appear as contested symbols of nature. Rather, environmentalist news sources gain entrée as political representatives for nonhuman animals. The dominant environmentalist discourse 
defines resort-based skiing as an ecologically illegitimate mode of interaction with this mountain environment.

A recurring pro-resort discourse, which is articulated by Jumbo Glacier Resort project proponents as well as by some journalists, focuses on how the resort will bring tourism and economic development to a region with a declining forestry economy (10 out of 36 articles). Skiing is defined as a mode of "attractive development" (Luke 2002), which values nonhuman nature for the experience it provides, rather than as a resource pool for forestry or mining. For example, developer Oberto Oberti, who is routinely featured as a news source, is paraphrased as follows: "He argues the project would create jobs in a part of British Columbia where unemployment is a serious problem and that it would cement the province's reputation as a top ski destination" (Greenwood 2004b:FP05). Related themes focus on the physical features that will work as tourism attractors and will connect the region to global flows of tourism mobility (Sheller and Urry 2004). With the longest vertical drop in North America and year-round glacier skiing, the area is defined as an "ideal" location for a ski resort. For example, Greenwood leads into a National Post article on the delays faced by the project as follows, "If there is such a thing as the perfect ski hill, Oberto Oberti believes he has found it. Jumbo Glacier ... is a wilderness of spectacular views, seemingly endless slopes and, best of all, a climate that allows for generous snowfalls of powder even in midsummer" (Greenwood 2004a:FP01). With the exception of two articles from the National Post, the media narrative does little to link the resort development to the notion of sustainable development. Instead, the environment is the discursive terrain of environmentalists, while resort proponents represent tourism and employment opportunities. This sets up the following binary opposition: grizzly bears/wilderness/environmentalists versus ski resort/tourism/resort proponents/provincial government.

\section{Websites}

The Jumbo Pass area is defined as home to grizzly bears and much of the focus of the websites is on the need to protect these large animals from resort building and mass tourism (Jumbo Creek Conservation Society 2009; Wildsight 2009). Grizzlies are described as susceptible to the development that accompanies the resort, such as road building. Other negative impacts include habitat degradation, human-caused mortality and limitations on the range of grizzly movement. There are several visual representations of grizzlies and the bears serve as icons of wilderness. Visual imagery communicates environmentalist frames and renders environment harm culturally meaningful, local, and politically con- 
sequential (Smith and Joffe 2009). Our findings similarly suggest that environmental organizations use visual imagery, such as grizzly bears, in their websites to elevate concern and environmental awareness.

The images on activist websites, as well as on Facebook pages and in You Tube videos, generally portray nature in a pristine state, with no human activity present. However, some photos depict hiking, which suggests that this is an acceptable mode of interaction with the Jumbo environment (Jumbo Creek Conservation Society 2009; Valhalla Wilderness Society 2009; Wildsight 2009). Some websites also propose alternatives to the resort by emphasizing that there are several local ski resorts within a few hours of the site. These venues are described as operating below capacity, suggesting that Jumbo Resort represents excessive development for this wilderness area. This discourse focuses on Jumbo Resort as a specific example of ecologically illegitimate ski development, rather than framing skiing in general as a problem. The theme that support should go to existing resorts rather than towards developing new resorts is present in mass media coverage, but it is marginal. This discourse is articulated in activist-produced web content to a greater degree than in the mass media, creating a space for potential alignment between environmental organizations and environmentally aware skiers.

Climate change, which is not discussed in mass media coverage, is also described as a severe problem on the websites (Jumbo Creek Conservation Society 2009; Wildsight 2009). Climate change is depicted as an issue of urgency, which is conveyed through studies that predict the glaciers in the region will melt within four decades without the additional strain of the resort. This brings attention to the time-sensitive nature of climate change, but also to the irreparable damage that has already been done. A main claim of the websites is that the environmental harms of climate change will be exacerbated by the increased presence of skiers.

The websites routinely use scientific evidence to support their claims about grizzly bear populations and climate change. Scientific research is used as evidence that grizzly bear populations cannot withstand the additional ecological pressure of building and maintaining a large ski resort. According to a study conducted by the Ministry of Environment, grizzly populations have diminished 40\% between 2004-2007 (Nelson EcoSociety 2009). Biologists and scientists are frequently used as authoritative voices to legitimize assertions that grizzly decline and recovery programs are expensive, but also that planned mitigation efforts linked to the resort development are meaningless (Nelson EcoSociety 2009, Valhalla Wilderness Society 2009, Wildsight 2009). Scientific knowledge on grizzlies and climate change is featured more often in websites than in mass media coverage. This is not surprising given the different formats 
of print media and online media. However, this illustrates how activists use the internet as a tool to produce content that reflects issues from their perspective, forgoing some of the constraints of accessing traditional media (Gamson and Wolfsfeld 1993).

\section{Local Democracy and Environmental Governance}

\section{Mass media}

A significant body of research examines the degree to which nonstate actors gain access to - and power within - processes of environmental governance (Bulkeley and Betsill 2005; Mascarenhas and Scarce 2004; Parkins and Davidson 2008). Other work similarly examines connections between environmentalism and a "reconceptualization of citizenship as participatory, expansive, solidaristic, and ecological" (Adkin 2009:4; also see Salazar 2009). Questions of local decision-making within environmental governance are central to the Jumbo Pass news narrative (17 of 36 news articles). However, the meaning of local decision-making varies across news articles and is contested by different groups. An article from 2004, for example, describes how the provincial government is shifting decision making over the proposed resort to the Regional District of East Kootenay (RDEK). The provincial government frames this move as a sign of respect and empowerment for local communities. However, the initial response from environmentalists is that the province is "trying to 'pass the buck' for an unpopular decision" onto a local system that is not well equipped to understand the complexities of the issue (Hartwig quoted in Hume 2004a:A11).

Environmental discourse quickly shifts, however, and links local decision-making to widespread opposition to the project in nearby communities. For example, a Canadian Press article reports, "Jumbo opponent Dave Quinn said 90 per cent of people who took part in the provincial government's environmental assessment on the resort at public meetings in Nelson and Invermere were opposed to the project" (Canadian Press 2007:S3). Similarly, a 2008 article informs readers that "Jumbo opponents, including Wildsight, want the decisions to remain in local hands" (Stueck 2008:S2). Local decision-making is preferred to provincial decision-making because it gives members of East Kootenay communities greater control over development in the region. After reviewing the Jumbo conflict, columnist Mark Hume echoes environmentalist discourse as he writes, "The provincial cabinet will issue a ruling next fall. But the people of the Kootenays should really be the ones to make the decision - after all, they live there" (Hume 2004b:A15). 
In opposition to environmentalist discourse, two op-ed pieces from the National Post reframe local control over the project as undemocratic. They claim that local governments are easily manipulated by environmentalists and a small number of particularly vocal opponents, derisively described as a

by-now familiar collection of ideological leftists, environmentalists and eco-freaks, Luddites, NIMBYs, aboriginals, agenda-driven bureaucrats, self-interested local businesses and even manipulative schoolteachers in short, the baying hounds of post-modern hell. (Koch and Weisssenberger 2003:FP11)

Elsewhere, Koch (2007:FP19) writes in the National Post, "Desperate to stop Jumbo, opponents have been pressuring the regional district to impose death-by-zoning." Environmentalists and opponents are positioned against the resort developers, who are described as patiently working through the appropriate procedures laid out by the province. It is noteworthy that this pessimistic framing of local governance is articulated only by a couple of newspaper columnists, rather than by resort developers. News sources from Jumbo Glacier Resort may, by contrast, wish to avoid claims that may be read as derisive of the local community.

Another notable patterned silence concerns the relative absence of First Nations groups (such as the Ktunaxa and Sinixt) in discussions of local decision-making. Where First Nations concerns with the project are raised, in seven articles, Ktunaxa or Sinixt news sources rarely appear to speak on their own behalf, but are talked about by columnists, environmentalists, or government news sources. This finding is consistent with research that notes the selective incorporation of First Nations political claims into eco-politics (Hipwell 2009; Stoddart 2007; Willems-Braun 1996-1997).

\section{Websites}

The need for local decision-making about the resort is stressed in all of the websites, Facebook pages, and You Tube videos related to the Jumbo Pass conflict. Website viewers are encouraged to demand that the decision be kept local through tactics such as letter writing (JCCS 2009; Wildsight 2009). Jumbo Creek Conservation Society and Wildsight provide a list of the RDEK board members and indicate whether they voted to keep the decision local, or to pass the decision to the provincial government. This is a good example of information provision on the internet that would not likely occur via traditional media such as national or provincial newspapers. 
Each of the websites describes provincial decision-making as less democratic than local decision-making. The provincial government is often accused of not adhering to the demands of local regions that surround the proposed resort site, making decisions behind closed doors, and taking too long to address a time-sensitive issue. According to the Valhalla Wilderness Society (2009) webpage, a nonbinding plebiscite conducted in the RDEK shows that $78 \%$ of the respondents are against Jumbo Resort. A third party poll commissioned by Wildsight (2009) also showed that voters in the Kootenays are against the resort: $19 \%$ favour the resort, $63 \%$ oppose it. This information reinforces the notion that citizens living in the region of the proposed resort do not want it there. Websites argue that by not adhering to the wishes of local citizens, resort developers and government officials are ignoring the majority of people who will be affected most (Valhalla Wilderness Society 2009; Wildsight 2009). Moreover, there is frustration over an 8-7 vote in August 2009, where RDEK directors asked the province to make the Jumbo site into a "Mountain Resort Municipality," consisting of an unelected council appointed by the provincial government (Wildsight 2009). Environmental groups fear this action has taken control over Jumbo Pass even further out of local hands.

While environmentalist websites do not serve as a venue for Sinixt or Ktunaxa claims-makers to represent themselves, First Nations concerns with the resort are included in both the Valhalla Wilderness Society (2009) and Wildsight (2009) websites. For example, the Valhalla Wilderness Society website claims that Ktunaxa people oppose Jumbo because treaty issues and indigenous rights must be dealt with before any large tracts of land are considered for further development. Furthermore, Sinixt and Ktunaxa speakers do appear and articulate their concerns with the resort in You Tube videos that focus on a 2008 road blockade and a 2011 rally against the resort. This suggests that Web 2.0 applications may be creating space for a wider range of voices within social movement opposition to Jumbo Glacier Resort.

\section{Repertoires of Protest}

\section{Mass media}

Less than a third of the newspaper articles (10 out of 36) mention specific strategies and protest tactics environmentalists used to bring attention to the Jumbo Pass conflict. The tactics that receive coverage include: blockades, petitions, a legal challenge to the project from RK Heli-Skiing, NHL defenseman Scott Niedermayer's endorsement of the campaign, letter-writing campaigns, benefit concerts by singer Bruce Cockburn, 
lobbying the government, and putting pressure on project investors to divest from Jumbo Glacier Resort. There is not a large discrepancy among the number of news stories that focus on each of these different tactics, which constitute the "repertoires of protest" used by environmentalists in this campaign (Tilly and Tarrow 2007). Only a handful of articles (ranging from one to three) discuss any specific protest tactic. However, there are differences in the types of news narratives associated with coverage of different protest tactics and political strategies.

The road blockades, which lasted for several weeks in August and September 2008, were initiated by an attempt to begin "temporary" construction in the Jumbo Pass area. This dramatic protest was described in two articles from the Globe and Mail (Bassett 2008; Stueck 2008). Ultimately, no protesters were arrested for this action and the developer backed off the planned construction. While the blockades were useful for gaining media access, the dominant theme was simply that the project is "controversial." Little attention was given in these articles to substantive claims about grizzly bear impacts, wilderness values, or calls for local decision-making. The news stories that focus on blockades are consistent with prior research that suggests that reliance on particularly dramatic protest tactics risks minimizing attention to the substantive claims of social movement groups (Doyle 2003; Gitlin 1980).

Petitions and legal challenges lack the drama and imagery of protesters blockading access roads. Stories that discuss the petitions focused on the wilderness values of the area and environmentalists' interest in maintaining local decision-making over the project. For example:

The proposed development at Jumbo Glacier has already stirred considerable controversy in the Kootenays, where thousands of people have signed petitions, calling it an unwanted commercial intrusion into a wilderness area. But despite those protests, the project got a major push forward last fall when the province granted environmental approval (Hume 2005:S1).

By contrast, coverage of RK Heli-ski's legal challenge (based on infringement of their existing tenure agreements with the provincial government) focused more on issues of local decision-making than on ecological concerns with the project (Scotton 2005).

Environmental organizations often try to enrol celebrities in their campaigns, as a hook for media coverage (Boykoff and Goodman 2009; Brockington 2008). The Jumbo Pass campaign has drawn on NHL defenseman Scott Niedermayer, as well as singer Bruce Cockburn. Niedermayer is an NHL all-star, Canadian Olympic gold medal winner, and multiple Stanley Cup winner. His call to "Keep Jumbo Wild" gave the issue visibility in the Globe and Mail. In an article titled, "NHL Star Joins 
Fight Against Resort Developer," the reader is told, "Mr. Niedermayer ... first went into the Jumbo Creek watershed when he was a boy, hiked through the area a few years ago, returned this summer, and believes it is remarkable wilderness that should be protected from development" (Hume 2007:S1). This article on Niedermayer's participation includes substantive claims about grizzly bear impacts, wilderness values, and local decision-making — all of the major discursive themes articulated by environmentalists. Similarly, a benefit concert staged by Bruce Cockburn resulted in a feature article in the Globe and Mail (Stueck 2008). Attempts to celebritize the Jumbo campaign were relatively successful, both in terms of gaining news access and in conveying environmentalists' substantive claims.

\section{Websites}

E-mail and letter writing are the most popular forms of protest incorporated into the websites. Postal and/or e-mail addresses are provided and include regional directors, regional board members, and provincial politicians, including the premier (Jumbo Creek Conservation Society 2009, Valhalla Wilderness Society 2009, Wildsight 2009). Sample letters, how to write the letter, and what points to include are also provided. Key points to cover include keeping the decision about the resort local, opposing the formation of a corporate Resort Municipality, keeping the proceedings public, and challenging the extension of the Environmental Assessment certificate. Additional options are to phone relevant government ministers (phone numbers are usually provided), or to write to the local newspaper. Although the use of the internet facilitates forms of collective action such as letter writing, in this case the process is heavily guided by the website.

Several celebrities are incorporated into activist-produced web content as supporters or spokespeople to "Keep Jumbo Wild." These include hockey player Scott Niedermayer, musician Bruce Cockburn, CBC host and author Bruce Kirkby, mountaineer Pat Morrow, Canada's National Men's Downhill Ski Team Coach for the Olympics Helmut Spiegle, and Olympic Cross Country gold medalist Becky Scott. The presence of iconic skiers and ski coaches who oppose the development contrasts with media coverage of the issue. A photo of Niedermayer serves as the link to the "take action" page on the Jumbo Creek Conservation Society webpage. Niedermayer also features prominently in the "Alas Resort" You Tube video, which promotes the Jumbo Creek Conservation Society website and has received 8,807 views. The celebritization of the issue is used to encourage letter writing and indicates that these groups are making use of celebrities in a direct way to involve viewers in activism, 
rather than only as a hook to gain news coverage, as is often the case when environmental issues are incorporated into the "politicized celebrity system" (Boykoff and Goodman 2009).

Other tactics used to raise awareness about the issue are the production of the "Jumbo Wild" coffee by Kicking Horse Coffee, an Invermerebased coffee roaster with an organic and fair trade orientation that has national distribution (Wildsight 2009). In addition, websites include calls for donations or funding, and provide information on outreach programs, media campaigns, education, research, and collaboration among groups that form a broad constituency in support of environmental protection (Jumbo Creek Conservation Society 2009, Valhalla Wilderness Society 2009, Wildsight 2009). The Jumbo Creek Conservation Society also uses its "Jumbo Wild" Facebook group to promote awareness of Jumbo Pass and encourages viewers to order "Jumbo Wild" bumper stickers to advocate protection for the area. It is apparent from the variety of protest tactics found online that the internet is a useful tool for activists in their effort to engage citizens (della Porta and Mosca 2005; Rohlinger and Brown 2009).

\section{Environmentalists' Use of Web 2.0}

Of the environmental organizations involved in this conflict, the Jumbo Creek Conservation Society takes particular advantage of Facebook to mobilize opposition to Jumbo Glacier Resort through their "Jumbo Wild" Facebook group, which has 236 members and is updated regularly. It provides information on the progress of the resort, links to relevant material by environmental organizations, and links to newspaper articles about the conflict. The Facebook page and the group's website are also linked to each other, providing an easy means for viewers to move between the two sites.

You Tube videos of a 2008 road blockade against resort developers ( 1,298 views) and a short documentary titled "Alas Resort" $(8,807$ views) feature prominent links to the Jumbo Creek Conservation Society website. Video of a 2011 rally against the resort held in Nelson, BC, also features links to the Jumbo Creek Conservation Society and the West Kootenay EcoSociety (881 views). Jumbo Creek Conservation Society, and to a lesser extent the West Kootenay EcoSociety, are taking advantage of You Tube to promote the Jumbo issue to a broader audience. 


\section{Conclusion}

Environmentalists are able to gain entrée to the news narratives constructed around the Jumbo Pass conflict, often without the aid of dramatic protest actions. They are able to articulate substantive claims about the negative impacts of the ski resort on grizzly bear habitat and on the wilderness values of this alpine environment. They further connect their ecological claims to concerns about local environmental governance. The relationship between environmentalists and news media, as examined in this case, appears to be one in which environmentalists are treated as "authorized knowers" and are given the power to speak on behalf of nature (Ericson et al. 1989). Rather than reflecting asymmetrical dependency, our analysis is consistent with Cottle's (2008) recent suggestion that relationships between movements and media are changing due to several factors, including generational shifts among news workers (wherein younger news workers are seen as more sympathetic to many social movement goals).

The internet provides space for a greater range of claims and more nuanced claims than are admitted into the newspaper narrative. This is evident from the detailed information that is provided in the websites with respect to scientific knowledge, local democracy, and claims that climate change is transforming the Jumbo Pass landscape. The internet allows movements to disseminate information they feel is most valuable to gain support for their claims, outside the boundaries of news work. The increasing ability of social movements to speak directly to audiences through the internet may further mitigate relationships of asymmetrical dependency between movements and media (della Porta and Mosca 2005; Hackett and Carroll 2006; Lester and Hutchins 2009; Owens and Palmer 2003; Rohlinger and Brown 2009). While activist-produced websites are useful tools for environmental groups, their utility should not be overstated. Without further research on the different audience size and make-up for mass media and activist-produced media we cannot make confident assertions about the efficacy of environmentalist-produced web pages as a communication medium. However, newspapers like the Vancouver Sun and Globe and Mail likely reach a larger and broader audience than that reached by environmentalist websites. By contrast, activist-produced web content is likely limited to smaller, more attentive audiences who have the motivation to seek it out (Rauch 2007; Schroder 2000). If this is the case, social movement communication strategies should focus on how these different media may be used to complement each other. For example, mass media coverage may provide the necessary motivation for 
sympathetic audience members to seek out the more detailed content of activist-produced websites (Owens and Palmer 2003).

A broader range of protest tactics are promoted online than appear in newspaper coverage. E-mail and letter writing campaigns are popular tactics that are directly incorporated into the websites. What to write, how to do it, as well as contact addresses are all provided on the same page, making it easy to engage in this form of activism. The internet extends the communicative capacity of environmental organizations beyond the genre conventions of the mass media by directly mobilizing supporters to acts of "low-cost activism," such as letter writing or contributing donations (Tindall 2002).

While these features of the internet are valuable for social movements, they represent what Earl and Kimport (2011) term a "supersize" model of online activism, where new media technologies facilitate established modes of collective action. Greenberg and MacAulay offer an explanation for social movements' limited use of the participatory potential of the web. They note that the communication strategies of nongovernmental organizations tend to be "geared less to achieving mutual understanding through an open-ended process of exchange, than upon securing successful outcomes, whether that's measured in terms of funds raised, policies changed or memberships/subscriptions sold" (Greenberg and MacAulay 2009:74). Similarly, Stein (2009) notes that environmental organization webmasters emphasize information, resource generation and mobilization, rather than linking, dialogue, and creative expression. The website practices of organizations mobilizing to protect Jumbo Pass largely adhere to this hierarchy of priorities. However, taking greater advantage of the "affordances" of the internet, which permit collective action without physical and temporal co-presence, can lead to unique "Web 2.0" modes of protest that are not simply online versions of previously offline tactics (Earl and Kimport 2011). In our analysis of media use in the Jumbo Pass conflict, we saw few signs that environmental organizations are taking full advantage of internet technologies, including Web 2.0 applications like Facebook, Twitter, Wikipedia, or You Tube, to create new additions to their "repertoires of protest" (Tilly and Tarrow 2007). It may be, as some argue, that the structure of social movement organizations needs to change before movements are able to take full advantage of the communicative possibilities opened up by the internet (Fine 2006; Pickerill 2003).

Finally, questions about audience constitution and engagement cannot be answered through a textual analysis of newspaper coverage and environmentalist websites. Further research on who the audiences are for these different types of media would be useful. Further research might 
also examine how these different media cultivate different modes of audience engagement. While social movements use the internet to promote political participation in ways not possible in the news media, we do not know whether website audiences are any more politically active than mass media audiences.

\section{REFERENCES}

Adkin, Laurie E. 2009. Ecology, citizenship, democracy. Pp. 1-15 in L.E. Adkin, ed., Environmental Conflict and Democracy in Canada. Vancouver: UBC Press.

Arvai, Joseph L. and Michael J. Mascarenhas. 2001. Print media framing of the environmental movement in a Canadian forestry debate. Environmental Management 27(5):705-714.

Barnes, Barbara A. 2009. "Everybody wants to pioneer something out here": Landscape, adventure, and biopolitics in the American southwest. Journal of Sport and Social Issues 33(3):230-256.

Bassett, Dean. 2008. Protesters block Jumbo Glacier construction. The Globe and Mail, 6 August, S3.

Becker, Howard S. 2002. Studying the new media. Qualitative Sociology 25(3):337-343.

Boykoff, Jules. 2006. Framing dissent: Mass-media coverage of the global justice movement. New Political Science 28(2):201-228.

Boykoff, Maxwell T. and Michael K. Goodman. 2009. Conspicuous redemption? Reflections on the promises and perils of the "celebritization" of climate change. Geoforum 40:395-406.

Brockington, Dan. 2008. Powerful environmentalisms: Conservation, celebrity and capitalism. Media, Culture \& Society 30(4):551-568.

Bulkeley, Harriet and Michele Betsill. 2005. Rethinking sustainable cities: Multilevel governance and the "urban" politics of climate change. Environmental Politics 14(1):42-63.

Canadian Press. 2007. Referendum called for over Jumbo Glacier Resort. The Globe and Mail, 20 April, S3.

Carroll, William K. and Robert A. Hackett. 2006. Democratic media activism through the lens of social movement theory. Media, Culture \& Society 28(1):83-104.

Carroll, W.K. and R.S. Ratner. 1999. Media strategies and political projects: A comparative study of social movements. Canadian Journal of Sociology 24(1):1-34.

Cormier, Jeffrey and D.B. Tindall. 2005. Wood frames: Framing the forests in British Columbia. Sociological Focus 38(1):1-24. 
Cottle, Simon. 2008. Reporting demonstrations: The changing media politics of dissent. Media, Culture \& Society 30(6):853-872.

Cukier, Wendy and Catherine Middleton. 2003. Evaluating the web presence of voluntary sector organizations: An assessment of Canadian web sites. IT \& Society 1(3):102-130.

della Porta, Donatella and Lorenzo Mosca. 2005. Global-net for global movements? A network of networks for a movement of movements. Journal of Public Policy 25(1):165-190.

Doyle, Aaron. 2003. Arresting Images: Crime and Policing in Front of the Television Camera. Toronto: University of Toronto Press.

Doyle, Aaron, Brian Elliott, and David Tindall. 1997. Framing the forests: Corporations, the B.C. Forest Alliance, and the media. Pp. 240-268 in W.K. Carroll, ed., Organizing Dissent: Contemporary Social Movements in Theory and Practice. Toronto: Garamond Press.

Earl, Jennifer and Katrina Kimport. 2011. Digitally Enabled Social Change: Activism in the Internet Age. Cambridge, MA: MIT Press.

Ericson, R.V., P.M. Baranek, and J.B.L. Chan. 1989. Negotiating Control: A Study of News Sources. Toronto: University of Toronto Press.

Fine, Allison H. 2006. Momentum: Igniting Social Change in the Connected Age. San Francisco: Wiley.

Gamson, William A. 2007. Bystanders, public opinion, and the media. Pp. 242261 in D.A. Snow, S.A. Soule, and H. Kriesi, eds., The Blackwell Companion to Social Movements. Oxford: Blackwell.

Gamson, W.A. and G. Wolfsfeld. 1993. Movements and media as interacting systems. Annals of the American Academy of Political and Social Science 528:114-125.

Gitlin, Todd. 1980. The Whole World is Watching: Mass Media in the Making and Unmaking of the New Left. Berkeley, CA: University of California Press.

Greenberg, Josh and Maggie MacAulay. 2009. NPO 2.0? Exploring the web presence of environmental nonprofit organizations in Canada. Global Media Journal 2(1):63-88.

Greenwood, John. 2004a. Investors wait since 1991 on ski resort plan: Regulatory faceoff. National Post, 12 January, FP01.

2004b. Stringent conditions could scuttle resort plan: Local residents and First Nations hold key to future of Jumbo Glacier project. National Post, 20 October, FP05.

Hackett, Robert A., and William K. Carroll. 2006. Remaking Media: The Struggle to Democratize Public Communication. New York: Routledge.

Hackett, R.A., R. Gruneau, D. Gutstein, T.A. Gibson, and NewsWatch Canada. 2000. The Missing News: Filters and Blind Spots in Canada's Press. Ottawa: Canadian Centre for Policy Alternatives \& Garamond Press. 
Hannigan, John A. 2006. Environmental Sociology: A Social Constructionist Perspective. Second edition. London: Routledge.

Hansen, Anders. 2010. Environment, Media and Communication. London: Routledge.

Hesse-Biber, Sharlene Nagy, and Patricia Levy. 2008. Handbook of Emergent Methods. New York: The Guilford Press.

Hine, Christine. 2005. Internet research and the sociology of cyber-social-scientific knowledge. Information Society 21(4):239-248.

Hipwell, William T. 2009. Environmental conflict and democracy in Bella Coola: Political ecology on the margins of industria. Pp. 140-158 in L.E. Adkin, ed., Environmental Conflict and Democracy in Canada. Vancouver: UBC Press.

Hume, Mark. 2004a. B.C. Backcountry draws a crowd. The Globe and Mail, 18 December, $\mathrm{T} 2$.

2004b. The people of the Kootenays don't want another Whistler, The Globe and Mail, 9 March, A15.

2005. Heli-ski firm trying to block resort. The Globe and Mail, 18 June, S1.

2007. NHL star joins fight against resort developer The Globe and Mail, 17 September, S1.

Jumbo Creek Conservation Society (JCCS). (2009). Retrieved from http://www. keepitwild.ca/ Accessed November 21, 2009.

Juris, Jeffrey. 2008. Networking Futures. Durham, NC: Duke University Press.

Koch, George. 2007. B.C. resorts face death by zoning. National Post, 18 April, FP19.

Koch, George and John Weissenberger. 2003. Jumbo controversy: A visionary architect wants to bring a world-class ski resort to a logged-over B.C. valley. Eco-freaks respond with "grizzlies not gondolas" bumper stickers. National Post, December 19, FP11.

Kousis, Maria. 2000. Tourism and the environment: A social movements perspective. Annals of Tourism Research 27(2):468-489.

Lester, Libby and Brett Hutchins. 2009. Power games: Environmental protest, news media and the internet. Media, Culture \& Society 31(4):579-595.

Lindlof, Thomas R. and Milton J. Shatzer. 1998. Media ethnography in virtual space: Strategies, limits, and possibilities. Journal of Broadcasting and Electronic Media 42(2):170-189.

Luke, Timothy W. 2002. On the political economy of Clayoquot Sound: The uneasy transition from extractive to attractive models of development. Pp. 91-112 in W. Magnusson and K. Shaw, eds., A Political Space: Reading the Global through Clayoquot Sound. Montreal and Kingston: McGillQueen's University Press.

Macdonald, Myra. 2003. Exploring Media Discourse. London: Arnold. 
Mascarenhas, Michael and Rik Scarce. 2004. "The intention was good": Legitimacy, consensus-based decision making, and the case of forest planning in British Columbia, Canada. Society and Natural Resources 17:17-38.

Mason, Jennifer. 2002. Qualitative Researching. Second edition. London: Sage Publications.

Nash, Roderick Frazier. 2001. Wilderness and the American Mind. New Haven: Yale University Press.

Nelson EcoSociety. (2009). http://ilovenelson.com/eco-society-update-4/ Accessed November 27, 2009.

Orlikowski, W.J. 1992. The duality of technology: Rethinking the concept of technology in organizations. Organization Science 3(3):398-427.

Owens, Lynn and L. Kendall Palmer. 2003. Making the news: Anarchist counterpublic relations on the World Wide Web. Critical Studies in Media Communication 20(4):335-361.

Parkins, John and Debra Davidson. 2008. Constructing the public sphere in compromised settings: Environmental governance in the Alberta forest sector. Canadian Review of Sociology 45(2):177-196.

Philo, Chris and Chris Wilbert, eds. 2000. Animal Spaces, Beastly Places: New Geographies of Human-Animal Relations. London and New York: Routledge.

Pickerill Jenny. 2003. Cyberprotest: Environmental Activism Online. New York: Manchester University Press.

Rauch, Jennifer. 2007. Activists as interpretive communities: Rituals of consumption and interaction in an alternative media audience. Media, Culture \& Society 29(6):994-1013.

Rohlinger, Deana A. and Jordan Brown. 2009. Democracy, action, and the internet after 9/11. American Behavioral Scientist 53(1):133-150.

Rossiter, David. 2004. The nature of protest: Constructing the spaces of British Columbia's rainforests. Cultural Geographies 11:139-164.

Salazar, Debra. 2009. Saving nature and seeking justice: Environmental activists in the Pacific northwest. Organization \& Environment 22(2):230-254.

Schroder, Kim Christian. 2000. Making sense of audience discourses: Towards a multidimensional model of mass media reception. European Journal of Cultural Studies 3(2):233-258.

Schudson, Michael. 1989. The sociology of news production. Media, Culture \& Society 11:263-282.

Scotton, Geoffrey. 2005. Jumbo Glacier Resort plan inches forward: Proposed \$450-million ski destination still faces legal challenge, reviews, Vancouver Sun, 13 September, D4.

Sheller, Mimi and John Urry, eds. 2004. Tourism Mobilities: Places to Play, Places in Play. London: Routledge. 
Silverman, David. 2001. Interpreting Qualitative Data: Methods for Analysing Talk, Text and Interaction. Second edition. London: Sage.

Smith, N. W. and H. Joffe. 2009. Climate change in the British press: The role of the visual. Journal of Risk Research 12(5):647-663.

Smith, Jackie, John D. McCarthy, Clark McPhail, and Boguslaw Augustyn. 2001. From protest to agenda building: Description bias in media coverage of protest events in Washington, DC. Social Forces 79(4):1397-1423.

Song, Felicia Wu. 2008. Theorizing web 2.0: A cultural perspective. Information, Communication \& Society 13(2):249-275.

Stein, Laura. 2009. Social movement web use in theory and practice: A content analysis of US movement websites. New Media \& Society 11(5):749771.

2011. Environmental website production: A structuration approach. $\mathrm{Me}$ dia, Culture and Society 33(3):363-384.

Stoddart, Mark C.J. 2005. Wilderness or working forest? British Columbia forest policy debate in the Vancouver Sun, 1991-2003. Research in Social Movements, Conflict and Change 26:187-206.

2007. "British Columbia is open for business": Environmental justice and working forest news in the Vancouver Sun. Local Environment: The International Journal of Justice and Sustainability 12(6):663-674. 2011. Grizzlies and gondolas: Animals and the meaning of skiing landscapes in British Columbia, Canada. Nature and Culture 6(1):41-63.

Stueck, Wendy. 2008. Singer Cockburn joins fight against Glacier Resort. The Globe and Mail, 2 October, S2.

Tilly, Charles and Sidney Tarrow. 2007. Contentious Politics. Boulder, CO: Paradigm Publishers.

Tindall, David B. 2002. Social networks, identification and participation in an environmental movement: Low-medium cost activism within the British Columbia wilderness preservation movement. Canadian Review of Sociology \& Anthropology 39(4):413-452.

Valhalla Wilderness Society. (2009). http://www.vws.org/ Accessed: November 26, 2009.

Wildsight. (2009). http://www.wildsight.ca/ Accessed November 25, 2009.

Willems-Braun, Bruce. 1996-1997. Colonial vestiges: Representing forest landscapes on Canada's west coast. BC Studies 112:5-39.

Wilson, Brian. 2007. New media, social movements, and global sport studies: A revolutionary moment and the sociology of sport. Sociology of Sport Journal 24:457-477.

Wolch, Jennifer and Jody Emel, eds. 1998. Animal Geographies: Place, Politics, and Identity in the Nature-Culture Borderlands. London and New York: Verso. 
Dr. Mark C.J. Stoddart is an Assistant Professor in the Sociology Department at Memorial University of Newfoundland. His recent work has been published in Sociological Spectrum, Nature and Culture, Human Ecology Review, the International Review for the Sociology of Sport, Social Movement Studies, and BC Studies. He is the author of the book, Making Meaning out of Mountains: The Political Ecology of Skiing, which is forthcoming with UBC Press.

Laura MacDonald is a PhD Student in the Sociology Department at the University of British Columbia. Her research interests include new media, media democracy, symbolic boundaries and social movements. 
